Original Research Article

\title{
Evaluation of antiepileptic activity of trachyspermum ammi (ajwain oil) alone and as an adjuvant to diazepam in swiss albino mice
}

\author{
Latha S., Jyothi C. H.*, Krishnagouda Patil
}

Department of Pharmacology, JJM Medical College, Davangere, Karnataka, India

Received: 21 December 2017 Accepted: 29 January 2018

*Correspondence to:

Dr. Jyothi C. H.,

Email: dr.jyothich@gmail.com

Copyright: (C) the author(s), publisher and licensee Medip Academy. This is an openaccess article distributed under the terms of the Creative Commons Attribution NonCommercial License, which permits unrestricted noncommercial use, distribution, and reproduction in any medium, provided the original work is properly cited.

\begin{abstract}
Background: Epilepsy is defined as a group of chronic neurological disorders characterized by recurrent and unprovoked seizures. Taking into account high prevalence of epilepsy and the adverse effects of the current antiepileptic agents which leads to noncompliance, more attempts should be made to re-explore the natural sources for new drug discoveries.

Methods: The antiepileptic activity of Ajwain oil alone and as adjuvant to diazepam in swiss albino mice was evaluated using Maximum Electro Shock (MES) and Pentylenetetrazole (PTZ) induced seizure model. A total of forty eight ( $N=48$ ) swiss albino mice weighing 20-30g of either sex were used in the study. Animals were divided into 2 sets of 24 animals each, which were further divided into 4 groups of 6 animals each. In either set, control received - $2 \%$ Tween 80 $(10 \mathrm{mg} / \mathrm{kg})$; standard- Diazepam $(2 \mathrm{mg} / \mathrm{kg})$; Test drug- Ajwain oil $(75 \mathrm{mg} / \mathrm{kg})$ and Adjuvant group- Ajwain oil (75mg/kg) + Diazepam $(2 \mathrm{mg} / \mathrm{kg})$. All the drugs were given intraperitoneally $30 \mathrm{~min}$ before inducing seizures.

Results: One way ANOVA was used to compare the means of all the groups followed by post Hoc Tukey's test for statistical evaluation. In MES model, test drug showed statistically significant antiepileptic activity compared to control, however the results were comparable to standard. In PTZ, adjuvant therapy showed significant activity compared to standard, with a $\mathrm{p}$ value $<0.001$.

Conclusions: Therefore, authors conclude that Ajwain oil has significant antiepileptic activity.
\end{abstract}

Keywords: Ajwain oil, Antiepileptic activity, MES, PTZ

\section{INTRODUCTION}

Epilepsy is defined as a group of chronic neurological disorders characterized by recurrent and unprovoked seizures. ${ }^{1}$ Prevalence of epilepsy in India is about $0.5-1 \%$ of the total population. ${ }^{2}$ Currently available antiepileptic agents includes conventional drugs like phenytoin, carbamazepine, ethosuximide, sodium valproate, benzodiazepens and newer agents like lamotrigine, vigabatrin, felbamate, topiramate, levetiracetam, lacosamide and so on. The disease control with currently available antiepileptic drugs is only about 50-60\%. ${ }^{3}$ Also they are associated with various side effects like sedation, fatigue, dizziness, coordination disturbances (ataxia, dysarthria, diplopia), tremor, cognitive deficits, mood alterations, behavioral changes, nystagmus, gingival hyperplasia, hirsutism, hepatotoxicity, trigeminal neuralgia, nausea, vomiting and so on. ${ }^{4}$ Hence there is always a need for an alternative antiepileptic agent.

Trachyspermum ammi (Ajwain) is medicinally important seed spice, belonging to the family Apiaceaea which is native of Egypt and is cultivated in Iraq, Iran, Afghanistan, Pakistan, and India. In India, it is cultivated in Madhya Pradesh, Uttar Pradesh, Gujarat, Rajasthan, Maharashtra, Bihar and West Bengal. ${ }^{5}$ 
Ajwain is a potential herb, widely used for curing various diseases in humans and animals. The roots are diuretic in nature and the seeds possess excellent aphrodisiac properties. The seed of Ajwain is bitter, pungent and contain $2-4.4 \%$ brown colored oil known as Ajwain oil. The main component of this oil is thymol, which can be used as an antispasmodic and antihelminthic. This also has antihypertensive, hepatoprotective, bronchodilator, antimicrobial, antiinflammatory and antiplatelet activity. ${ }^{5}$

Recent studies have shown that trachyspermum ammi has antiepileptic activity. ${ }^{6}$ Herbal drugs possess similar efficacy with lesser side effects and there is also scarcity of studies regarding the same. Hence this study is to evaluate antiepileptic activity of Ajwain oil.

Objective of the study was to evaluate antiepileptic activity of Trachyspermum ammi (Ajwain oil) alone and as an adjuvant to diazepam in swiss albino mice.

\section{METHODS}

\section{Selection of animals}

A total of 48 male Swiss albino mice weighing about 20 $30 \mathrm{~g}$ were obtained from the animal house attached to department of pharmacology, JJM Medical College, Davangere. The animals were fed on standard pellet diet and water and were maintained under standard conditions of temperature, humidity and light (12 h light/12 h dark cycle).

\section{Inclusion criteria}

Healthy 48 albino mice of either sex in equal number weighing $20-30 \mathrm{~g}$.

\section{Exclusion criteria}

- $\quad$ Mice which were pregnant and diseased.

- Mice which are used previously for other experiments.

Duration of study was 1 month.

\section{Drugs and chemicals}

- $\quad$ Standard - Diazepam $(2 \mathrm{mg} / \mathrm{kg})^{7}$

- Control - $2 \%$ tween $80(10 \mathrm{ml} / \mathrm{kg})$ in sterile saline $(0.9 \%)^{8}$

- $\quad$ Test drug - Ajwain oil $(75 \mathrm{mg} / \mathrm{kg})^{7}$

- Ajwain oil was obtained from commercial dealers (CRYSALIS, Shiv market, Wazir Pur, Delhi).

The animals were divided into 2 sets of 24 animals each, which are further divided into 4 groups of 6 animals each.

- Group 1: Control-2\% tween $80(10 \mathrm{ml} / \mathrm{kg})$

- Group 2: Standard- Diazepam $(2 \mathrm{mg} / \mathrm{kg})$
- $\quad$ Group 3: Test drug- Ajwain oil $(75 \mathrm{mg} / \mathrm{kg})$

- $\quad$ Group 4: Adjuvant- Diazepam $(2 \mathrm{mg} / \mathrm{kg})+$ Ajwain oil $(75 \mathrm{mg} / \mathrm{kg})$

Ajwain oil emulsion was prepared using 2\% Tween 80 in sterile saline. Standard drug was dissolved in sterile saline. Antiepileptic activity was evaluated after 30min of intraperitoneal (i.p) administration of drugs.

\section{Models used for evaluating antiepileptic activity}

1. Maximum electro shock (MES)

2. Pentylenetetrazole (PTZ) induced seizures

\section{Maximum electro shock (MES)}

MES is used to screen the therapeutic efficacy of drugs against generalized tonic-clonic seizures which act by blocking of voltage sensitive sodium channels or drugs that block glutamate receptors. ${ }^{9-11}$

First set of 24 mice were given electroshock stimulation through trans-auricular electrodes which were priory covered with saline moistened cotton wool with a current of $12 \mathrm{~mA}, 50 \mathrm{~Hz}$ for $0.2 \mathrm{sec}$ using convulsiometer and were observed for 2 min. ${ }^{9}$

\section{Parameters observed:}

- Duration of hind limb tonic extension (HLTE).

- Duration of time to regain righting reflex (RRR) (from the end of HLTE till the animal can stand on 4 legs).

\section{Pentylenetetrazole (PTZ) induced seizure}

PTZ is a valid model for generalized myoclonic and absence seizure. PTZ is a CNS stimulant known to produce seizures by direct depolarization of central neurons as well as by action analogous to picrotoxin i.e. it binds to picrotoxin binding site and inhibits GABA mediated transmission. ${ }^{9-11}$

Next set of 24 mice was given chemo shock at the dose of $60 \mathrm{mg} / \mathrm{kg}$ using PTZ. ${ }^{12}$

Parameters observed:

- $\quad$ Percentage protection from seizure

- Time duration between injection of PTZ and onset of myoclonic jerks and onset of clonic seizure

\section{Statistical analysis}

Protection was recorded as percentage. Other values were expressed as Mean \pm Standard error of mean (SEM) and statistical significance was calculated by one way ANOVA followed by Post Hoc Tukey's test for intergroup comparison. $\mathrm{P}$ value $<0.05$ was considered significant. 


\section{RESULTS}

Table 1: Effect of Ajwain oil in MES model -values are expressed as mean \pm SEM.

\begin{tabular}{|c|c|c|c|}
\hline Groups & $\begin{array}{l}\text { Treatment } \\
\text { and dose }\end{array}$ & $\begin{array}{l}\text { Duration of } \\
\text { HLTE (sec) }\end{array}$ & $\begin{array}{l}\text { Duration for } \\
\text { RRR (sec) }\end{array}$ \\
\hline $\begin{array}{l}\text { Group1 } \\
\text { (control) }\end{array}$ & $\begin{array}{l}2 \% \text { tween } \\
80 \text { in sterile } \\
\text { saline - } \\
10 \mathrm{mg} / \mathrm{kg}\end{array}$ & $15.83 \pm 1.47$ & $79.00 \pm 11.50$ \\
\hline $\begin{array}{l}\text { Group } 2 \\
\text { (standard) }\end{array}$ & $\begin{array}{l}\text { Diazepam - } \\
2 \mathrm{mg} / \mathrm{kg}\end{array}$ & $12.17 \pm 0.40$ & $50.00 \pm 6.06$ \\
\hline $\begin{array}{l}\text { Group } 3 \\
\text { (test drug) }\end{array}$ & $\begin{array}{l}\text { Ajwain oil - } \\
75 \mathrm{mg} / \mathrm{kg}\end{array}$ & $12.05 \pm 0.83$ & $42.33 \pm 6.12$ \\
\hline $\begin{array}{l}\text { Group } 4 \\
\text { (standard } \\
+ \text { test } \\
\text { drug) }\end{array}$ & $\begin{array}{l}\text { Diazepam - } \\
2 \mathrm{mg} / \mathrm{kg}+ \\
\text { Ajwain oil - } \\
75 \mathrm{mg} / \mathrm{kg}\end{array}$ & $12.17 \pm 0.98$ & $52.33 \pm 3.20$ \\
\hline
\end{tabular}

The means of parameters of both MES and PTZ models were compared with control using one way ANOVA and represented in Table 1 and Table 2 respectively. This was followed by post hoc Tukey's analysis of control, standard and test groups. These results are represented in Table 3. p value of $<0.05$ was considered statistically significant.

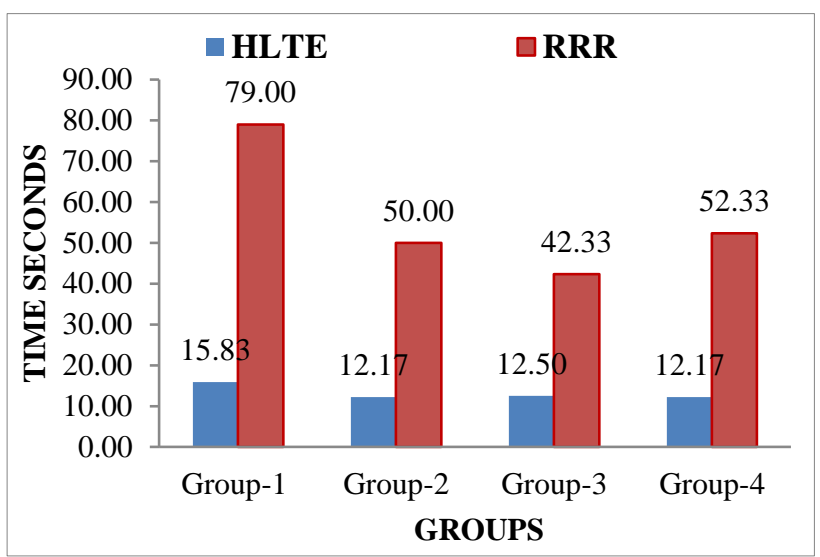

Group 1: Control (2\% tween 80 in sterile saline $-10 \mathrm{mg} / \mathrm{kg}$ ), Group 2: Standard (Diazepam -2mg/kg), Group 3: Test (Ajwain oil-75mg/kg) Group 4: Adjuvant group (Diazepam - 2mg/kg + Ajwain oil - $75 \mathrm{mg} / \mathrm{kg}$ )

Figure 1: MES model.

Table 2: Effect of Ajwain oil in PTZ induced seizures-Values are expressed as mean \pm SEM.

\begin{tabular}{|lllll|}
\hline Group & Treatment and dose & Protection & Onset of myoclonus & Onset of clonic seizures \\
\hline Group 1 (control) & $\begin{array}{l}\text { 2\% tween 80 in sterile saline - } \\
\text { 10mg/kg }\end{array}$ & $0 \%$ & $68 \pm 7048$ & $81 \pm 4.99$ \\
\hline Group 2 (standard) & Diazepam -2mg/kg & $66.66 \%$ & $160 \pm 7.58$ & $704 \pm 0$ \\
\hline Group 3 (test drug) & Ajwain oil - 75mg/kg & $0 \%$ & $161.66 \pm 22.78$ & $615.50 \pm 110.60$ \\
\hline $\begin{array}{l}\text { Group 4 (standard + } \\
\text { test drug) }\end{array}$ & $\begin{array}{l}\text { Diazepam -2mg/kg + Ajwain } \\
\text { oil - 75mg/kg }\end{array}$ & $83.33 \%$ & $300 \pm 0$ & 0 \\
\hline
\end{tabular}

Table 3: Post hoc Tukey's analysis of MES and PTZ models and significance.

\begin{tabular}{|c|c|c|c|c|}
\hline \multirow[t]{2}{*}{$\begin{array}{l}\text { Groups } \\
\text { comparison }\end{array}$} & \multicolumn{2}{|c|}{ Duration } & \multicolumn{2}{|c|}{ Onset of } \\
\hline & $\begin{array}{l}\text { Of } \\
\text { HLTE }\end{array}$ & $\begin{array}{l}\text { For } \\
\text { RRR }\end{array}$ & $\begin{array}{l}\text { Myo- } \\
\text { clonus }\end{array}$ & $\begin{array}{l}\text { Conic } \\
\text { seizures }\end{array}$ \\
\hline $\begin{array}{l}\text { Group } 1 \text { vs } \\
\text { Group } 2\end{array}$ & $\begin{array}{l}\mathrm{S} \\
\mathrm{P}<0.001\end{array}$ & $\begin{array}{l}\mathrm{S} \\
\mathrm{P}<0.001\end{array}$ & $\mathrm{~S} P<0.001$ & $\begin{array}{l}\mathrm{S} \\
\mathrm{P}<0.001\end{array}$ \\
\hline $\begin{array}{l}\text { Group } 1 \text { vs } \\
\text { Group } 3\end{array}$ & $\begin{array}{l}\mathrm{S} \\
\mathrm{P}<0.001\end{array}$ & $\begin{array}{l}\mathrm{S} \\
\mathrm{P}<0.001\end{array}$ & $S P<0.001$ & $\begin{array}{l}\mathrm{S} \\
\mathrm{P}<0.001\end{array}$ \\
\hline $\begin{array}{l}\text { Group } 1 \text { vs } \\
\text { Group } 4\end{array}$ & $\begin{array}{l}\mathrm{S} \\
\mathrm{P}<0.001\end{array}$ & $\begin{array}{l}\mathrm{S} \\
\mathrm{P}<0.001\end{array}$ & $\mathrm{~S} P<0.001$ & $\begin{array}{l}\mathrm{S} \\
\mathrm{P}<0.001\end{array}$ \\
\hline $\begin{array}{l}\text { Group } 2 \text { vs } \\
\text { Group } 3\end{array}$ & $\begin{array}{l}\text { NS } \\
(0.938)\end{array}$ & $\begin{array}{l}\text { NS } \\
(0.301)\end{array}$ & $\begin{array}{l}\text { NS } \\
(1.000)\end{array}$ & $\begin{array}{l}\text { NS } \\
(0.395)\end{array}$ \\
\hline $\begin{array}{l}\text { Group } 2 \text { vs } \\
\text { Group } 4\end{array}$ & $\begin{array}{l}\text { NS } \\
(1.000)\end{array}$ & $\begin{array}{l}\text { NS } \\
(0.946)\end{array}$ & $\mathrm{S} P<0.001$ & $\begin{array}{l}\mathrm{S} \\
\mathrm{P}<0.001\end{array}$ \\
\hline $\begin{array}{l}\text { Group } 3 \text { vs } \\
\text { Group } 4\end{array}$ & $\begin{array}{l}\text { NS } \\
(0.938)\end{array}$ & $\begin{array}{l}\text { NS } \\
(0.120)\end{array}$ & S P $<0.001$ & $\begin{array}{l}\mathrm{S} \\
\mathrm{P}<0.001\end{array}$ \\
\hline
\end{tabular}

S: Significant $(\mathrm{p}<0.05)$, NS: Not Significant $(\mathrm{p}>0.05)$, Group 1: Control (2\% tween 80 in sterile saline - $10 \mathrm{mg} / \mathrm{kg})$, Group 2: Standard (Diazepam -2mg/kg), Group 3: Test (Ajwain oil - 75mg/kg) Group 4: Adjuvant group (Diazepam $-2 \mathrm{mg} / \mathrm{kg}+$ Ajwain oil - $75 \mathrm{mg} / \mathrm{kg}$ )

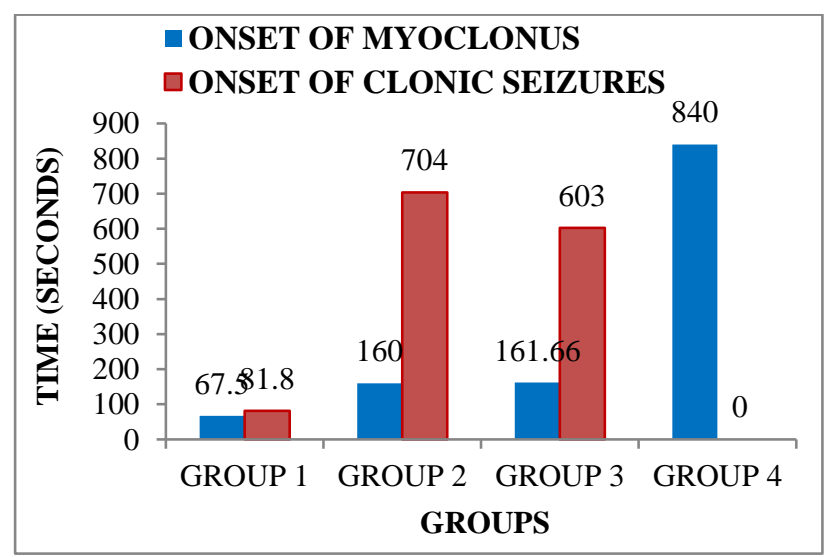

Group 1: Control (2\% tween 80 in sterile saline $-10 \mathrm{mg} / \mathrm{kg})$, Group 2: Standard (Diazepam -2mg/kg), Group 3: Test (Ajwain oil-75mg/kg) Group 4: Adjuvant group (Diazepam $-2 \mathrm{mg} / \mathrm{kg}+$ Ajwain oil - $75 \mathrm{mg} / \mathrm{kg}$ )

Figure 2: PTZ induced seizures. 


\section{MES model}

In this model efficacy is assessed by decrease in duration of HLTE and the time to regain righting reflex. When compared to control, Ajwain oil alone and as an adjuvant showed significant reduction in duration of HLTE and time to regain righting reflex $(\mathrm{p}<0.001)$. However, values of Ajwain oil as an adjuvant was comparable to standard.

\section{PTZ induced seizure model}

In this model efficacy is assessed by increase in the percentage of animals which do not develop seizures with PTZ and increase in duration of onset of myoclonic jerks and clonic seizures. In Ajwain oil as an adjuvant group showed $83.33 \%$ protection from seizures, compared to $66 \%$ in diazepam group and $0 \%$ in Ajwain oil alone group. Duration of onset of myoclonic and clonic seizures was increased in both Ajwain oil alone and as an adjuvant group, when compared to control $(\mathrm{p}<0.001)$. But Ajwain oil as an adjuvant group showed statistical significant results $(\mathrm{p}<0.001)$ when compared to standard and Ajwain oil alone.

\section{DISCUSSION}

Epilepsy is a common health problem throughout the world. Compliance with medication is a major problem because of the need for long term therapy together with unwanted side effects of many drugs.

Ajwain is highly valued medicinally important plant. The phytochemical studies of Ajwain seed revealed the presence of multiple phytoconstituents like thymine, tannins, steroptin, cumene and essential oil like thymol, $\gamma$ terpinene, $\rho$-cymene and other bioactive molecules. Gas chromatography mass spectrometry analysis of the essential oil of Ajwain showed that around 50\% of essential oil comprised of thymol. Thymol has been shown to specifically interact with synaptic neuronal functions and blocks neuronal $\mathrm{Na}+$ channels and is also a positive allosteric modulator of GABAA receptors, leading to increased chloride flux into the neuronal cells. ${ }^{7}$

In the above study, we have evaluated the antiepileptic activity of Ajwain oil using MES and PTZ model. MES model showed significant reduction in duration of HLTE and regain of righting reflex in Ajwain oil group when used alone and also as an adjuvant. Duration of HLTE, time taken to RRR provides information regarding recovery time. In PTZ model, percentage of protection from seizures and duration of onset of myoclonus and clonic seizures was increased in Adjuvant group compared to Ajwain alone. Increase in time duration between injection of PTZ and onset of seizures shows the drug is more effective.

This is in accordance with similar study which showed antiepileptic activity of Ajwain $(50 \mathrm{mg} / \mathrm{kg})$ was done by
Rajput MA, Khan RA et al, due to GABA facilitatory action using strychnine induced seizure model.

In MES and PTZ model at different dose also suggest its ability to block neuronal voltage-gated sodium channels and positive allosteric modulation of GABAA receptor and also there was no protection against strychnine and 4Aminopyridin-induced convulsions, which suggests it may not be acting on glycine receptor or potassium channel. So, in the present study the antiepileptic property of Ajwain oil is probably due to blocking of sodium channels and by GABA mimetic activity as explained above. Ajwain oil as an adjuvant has shown better antiepileptic activity when compared to diazepam alone or Ajwain oil alone. Therefore, it can be a source for future potential drug for the treatment of epilepsy alone or as add on drug to epilepsy thereby decreasing the dose and side effects and hence improving the compliance.

\section{CONCLUSION}

Based on the results of the present study, we conclude that Ajwain oil possess significant antiepileptic activity. However further studies are recommended to know exact mechanism of antiepileptic effect and to isolate the active compound(s) responsible for this pharmacological activity.

\section{ACKNOWLEDGEMENTS}

Authors would like to thank Dr. Shashikala G. H. M.D, Professor and HOD, of Dept. of Pharmacology, JJM Medical College, Davangere, Dr. Sushma H. K. M.D, Assistant Professor of Dept. of Pharmacology, JJM Medical College, Davangere. Dr. Kazi Nisar Ahmed B.Sc. animal house incharge in Dept. of Pharmacology, JJM Medical College, Davangere.

\section{Funding: No funding sources}

Conflict of interest: None declared

Ethical approval: The study was approved by the Institutional Ethics Committee (JJMMC/IAEC/10-2017)

\section{REFERENCES}

1. Fisher, RS. Epileptic seizures and Epilepsy: definitions proposed by the International League Against Epilepsy (ILAE) and the International Bureau for Epilepsy (IBE). Epilepsia. 2005;46:470.

2. Sridharan R, Murthy BN. Prevalence and pattern of epilepsy in India. Eplilepsia. 1999;40:631-6.

3. Jacobs MP, Leblanc GG, Brooks-kayal A, Jensen FE, Lowenstein DH, Noebels JL, et al. curing epilepsy: progress and future directions. Epilepsy behave. 2009; $14: 438-45$.

4. Roger PJ, Brain MS. Antiseizure drugs. In: Katzung BG, Masters SB, Trevor AJ, Editors. Basic and clinical pharmacology $12^{\text {th }}$ Ed. Newyork: Tata McGraw-Hill; 2012;403-427. 
5. Bairwa R, Sodha RS. Trachyspermum ammi. Pharmacogn Rev. 2012 Jan-Jun;6(11):56-60.

6. Rajput MA, Khan RA. evaluation of antiepileptic activity of methanol extract of Trachyspermum Ammi (L). Arch. Biol. Sci., Belgrade. 2013;65(3):815-9.

7. Sancheti J, Shaikh MF, Chaudhari R. Characterization of anticonvulsant and antiepileptogenic potential of thymol in various experimental models. Naunyn Schmiedeberg's Arch Pharmacol. 2013.

8. Gad SC, Cassidy CD. Nonclinical Vehicle Use in Studies by Multiple Routes in Multiple Species. International Journal of Toxicology. 2006;25:499521.

9. Gupta SK. Drug screening methods: preclinical evaluation of new drugs international students edition. Jaypee Brothers Medical Publishers. 2009;2:408-11.

10. Daniel D, Jeyaseeli F, Nandakumar K, Indumathi, Muralidhar. Anticonvulsant activity of alcoholic root extract of cardiospermum halicacabum. Brazilian Journal of Pharmacognosy. 2012 Jun;22(3):623-9.

11. Jain PD, Tambe RM, Sancheti JS, Nahire MS, Bhardwaj AK, Sathaye S. Screening of pistacia interrima extracts for their anticonvulsant activity in acute zebra fish and rodent models of epilepsy. Int $\mathrm{J}$ Nutr Pharmacol Neurol Dis. 2015;5:5662.

12. Vogel WH, Huger FP. Psychotropic and neurotropic activity. In: Vogel HG editor drug discovery and evaluation, Pharmacological assays. New York: springer. 2002;3:613-4.

Cite this article as: Latha $\mathrm{S}$, Jyothi $\mathrm{CH}$, Patil K. Evaluation of antiepileptic activity of trachyspermum ammi (ajwain oil) alone and as an adjuvant to diazepam in swiss albino mice. Int $\mathrm{J}$ Basic Clin Pharmacol 2018;7:400-4. 